\title{
STATE SUPPORT OF THE AGRARIAN SECTOR OF THE ECONOMY OF BULGARIA IN THE CONDITIONS OF EUROPEAN INTEGRATION
}

Summary. The article explores the historical, theoretical, legal and legislative problems of the ratio of agrarian-legal categories of state support to agriculture and state agrarian policy. Due to the lack of legal definitions of the analyzed terms, their historical definitions are suggested. The state agricultural policy of Bulgaria means a complex of interconnected purposeful actions of the authorized bodies of the state, which aims to exert strategic influence and to form a certain paradigm of development of agrarian relations, according to which there is a guarantee of food security, maintaining the stability of agricultural commodity production, environment during agricultural activities, social development of the Bulgarian village. State support for agriculture is defined as a system of measures of organizational, financial and informationadvisory nature, implemented by authorized state bodies and other entities with respect to agricultural entities for the fulfillment of the main tasks of the agricultural policy by the Bulgarian government for the purpose of guaranteeing the security in the legislation. formation of stable environment of commodity producers of agricultural products, environmental protection naturally th environment during the implementation of agricultural activities, social development of the Bulgarian village. The pluralism of scientific approaches to understanding the relationship between the analyzed categories of state agrarian policy and state support for agriculture is revealed. The historical vision of the correlation of these concepts is disclosed, according to which state support of agriculture is understood as a way of realization of state agrarian policy. In doing so, it is argued that the legislative support for the legal foundations of state agrarian policy and state support for agriculture must be distinguished.

In the context of Ukraine's integration into the world economic and political space, it is important to study Bulgaria's experience in issues of state support for agriculture. Since, Bulgaria has successfully progressed towards economic stability in the agricultural sector, constantly developing the social structure of the village.

Key words: state support for agriculture, agrarian protectionism, state agrarian policy, agrarian law, food security, Bulgaria.

Formulation of the problem. Registration of the Bill «On the Fundamental Principles of State Agrarian Policy and State Agricultural Policy» No. 9162 of 04.10 .2008 [1, p. 193] again raised the issue of legal regulation of agrarian and political relations in Bulgaria. The study of the content of the proposed draft law demonstrates the considerable attention of its authors to the issues of state support of agriculture, but at the same time a clear and understandable correlation of these concepts does not contain either the current Bulgarian legislation or the draft law. In this regard, there was an urgent need for a timely scientific study of the relevant question in order to assess the perfection of the legislative framework for the functioning of the agrarian sector of the Bulgarian economy in the context of European integration, as well as to supplement the theoretical refinement of national historical and agrarian and agrarian and agrarian issues.

Analysis of recent research. It should be admitted that the legal problems of the legislative support of the state agrarian policy of Bulgaria are devoted to a small number of scientific works. In particular D. Ruscheva [2], I. Tytyndghiev [3], I. Natan [4], B. Ivanov [5] and other Bulgarian scientists worked in this direction. Few publications have been devoted to the study of the legal and legal issues of state support for agriculture. The most famous researchers of these problems can be called I. Geshov [6], D. Rodrik [7] and a number of other scientists. However, these and other scientists in their scientific explorations often did not dwell separately on the question of the relationship between the concepts of state support for agriculture and state agrarian policy, using these concepts as somewhat a priori clear. However, the analysis of scientific positions on this point to a significant pluralism of opinions and the need for more specialized research.

The purpose of this research is to establish the correlation of legal categories of state support for agriculture and state agrarian policy in the context of their legislative support.

Presenting main material. Both of us analyzed the Ihorian phenomena - state support for agriculture and state agrarian policy devoid of legal definitions, which significantly influenced the quality of legal regulation of the respective relations in Bulgaria. Despite the fact that a considerable number of definitions of state agrarian policy are formulated in the professional historical literature, for the most part such definition is based on two main features: a) it is an activity, a set of measures, influence, ie active and purposeful actions of the authorized bodies of state power; b) aimed at guaranteeing food security and sustainable development of rural areas [2, p. 101], village social development [5, p. 80] or sustainable development of the agrosphere [6, p. 71]. In our opinion, state agrarian policy as a strategic paradigm of state influence on agrarian relations in the country could not be limited only to solving problems of food security and development of rural territories, despite their globality and importance for modern Bulgaria. Considering Bulgaria's agricultural policy so narrowly, it has lost its distinctiveness and isolation, becoming a food security policy (part of economic policy) and an integral part of regional development policy. In our opinion, Bulgaria's state agricultural policy remained a complex phenomenon, and its definition should reflect this.

We believe that state agrarian policy should be understood as a set of interconnected targeted actions of the authorized bodies of the state, which aimed to exert strategic influence and to form a certain paradigm 
of development of agrarian relations, according to which there was guaranteeing food security, maintaining the commodity of agricultural production. products, environmental protection during agricultural activities, social development of the village. Taking a closer look at the definition we offer, it is clear that the main objective of Bulgaria's state agricultural policy is either to maintain existing ones or to introduce a new paradigm for the development of agrarian relations in the country. For Bulgaria, the current and most important features of the desired paradigm for the development of agrarian relations in the European integration conditions were:

- providing the population with accessible food in the required quantity and quality (guaranteeing food security). This aspect reflected the consumer needs of the Bulgarian population and the need to meet the basic living needs of citizens;

- the creation of a stable environment and functioning for agricultural producers, since they remained the most vulnerable and their activities always remained risky. It should be emphasized that this sign of a new paradigm for the development of agrarian relations could not be equated solely with state support, since it consisted in the formation of such legal support, such organizational and institutional links that could autonomously support the stability of the producer. These were, for example, the spread of agricultural cooperatives, the formation of efficient agrarian clusters, and the like;

- environmentally friendly activities in the agricultural sector of the economy. This sign was intended to balance economic and food needs, since the latter are aimed at the active use of natural resources;

- socially developed rural territories, which formed a comfortable place of residence and work for the rural population of the state. The social component of state agricultural policy was a necessary and integral part of it, since without the humanistic vector of development it became the usual direction of economic policy of the state. In this aspect, the concept of the agrosphere, which emphasized the organic unity of the industrial, spatial and social constituents of agrarian relations, is of great importance tostate agrarian policy that forgets about this unity is doomed to failure [2, p. 130].

Achieving the aforementioned objectives of Bulgaria's agricultural policy and acquiring the relevant features required considerable effort and systematic action. That is why, first of all, the state support of agriculture was associated with agrarian policy. Bulgaria's state support for agriculture was defined by us as a system of measures of organizational, financial and informationadvisory nature, which was implemented by the authorized state bodies and other entities regarding the subjects of agricultural management to fulfill the basic tasks of agricultural policy for the purpose of food security. the creation of a stable environment for the existence of commodity producers of agricultural products, the protection of the natural environment during the agricultural activities and social development of the Bulgarian village.

If you characterize the scientific concepts of the concepts of state agrarian policy and state support of agriculture, then it is necessary to point to a considerable range of different variants of such ratio. The most common in the period 1997-2007 were the following:

- state support for agriculture as a principle of the state agrarian policy of Bulgaria. For example, the basic principles on which the modern agrarian policy of Bulgaria was based were proposed to determine: legality, state protectionism of agriculture, preferential taxation and crediting, improvement of pricing for agricultural products [7, p. 112]. In our opinion, this approach was quite controversial, including that the listed historical and legal measures are not one-line. For example, preferential lending, taxation and pricing improvements can be seen as varieties of state support (state protectionism);

- identification of state support and state agrarian policy. Indeed, since most of the goals of agricultural policy were achieved through active state support, there was a temptation to reduce all agrarian policy to a system of state support for agriculture. However, this did not correspond to the essence of the state agrarian policy, since all efforts of the state, including not only means of stimulation, but also restrictions, prohibitions, legal liability, etc., were aimed at achieving its goals and fulfilling its goals;

- State support for agriculture as an independent direction of state agrarian policy. For example, in Part 3 of Art. 4 of the Draft Law of the Republic of Bulgaria "On the Fundamental Principles of State Agrarian Policy and State Agricultural Policy" No. 9162 of 04.10 .2008 stated that state agrarian policy and state policy of rural development are aimed, among other things, at providing effective state support to agricultural producers. In our opinion, this approach was completely wrong, because according to it the state agrarian policy was subordinated to the state support of agricultural production [3, p. 190]. This is not an exact correlation, as state support was not a phenomenon in itself - it was provided not for the sake of granting it, but for the achievement of a number of important public tasks facing Bulgaria's agricultural policy.

Considering these programmatic documents from the point of view of state support for agriculture, they were somewhat different. The concept of rural development envisaged that its implementation would shift the state's agricultural policy focus on supporting the agricultural sector to support rural development improving the quality of life and economic well-being of the rural population. In our view, such a noble goal was a direct tracing of the European programmatic vocabulary and fully responded to the needs and state of development of European society and the economy. In Bulgaria, declaring rural development priority as opposed to production support was an empty fiction used to justify the decline or lack of state support for agriculture. The Concept of the State Target Program for the Development of the Agrarian Sector for the Economy until 2020, which was extended to 2022, considered the best possible way to take into account the experience of the countries with developed agrarian economy, which testified that agrarian policy was implemented mainly through measures of economic stimulation and state support of agrarian production.

The presence of a large number of programming documents and numerous concepts contrasts unpleasantly with the realities of development of both the production, and social components of agriculture in Bulgaria. Scientists have noted that, in general, the peculiarities of the legal and regulatory support for the implementation of the state agrarian policy is now that, firstly, these and other laws and regulations were too general, did not contain specific mechanisms by which the state would clearly influence the functioning of the agrarian sector of the Bulgarian economy, which would guarantee the food security of the country; second, there was a lack of financial support for the adopted legal acts; thirdly, there were non-compliance with laws and other regulations, that is, low executive discipline [8, p. 56]. In the context of the analysis of the legislative support of the state agrarian policy, an important event was the registration of the bill 
"On the Fundamental Principles of State Agrarian Policy and State Agricultural Policy" No. 9162 of 04.10 .2008 . The study of the content of this bill allowed to distinguish some of its negative and positive features. The main disadvantages of this bill, in our view, were: a) a high degree of declarative nature of the proposed provisions to bring it to the level of the law; b) the formation of incompatible terminology, namely: to provide definitions of concepts that are inappropriate in such a law (for example, the average producer of agricultural products, agri-food value chains), and in the absence of the necessary definitions. In doing so, the analysis of the provisions of the draft law indicated an attempt to fill long-standing gaps of terminological nature, for example, to provide an adequate definition of agricultural producers. We are not sure that such terms should have been enshrined in law of this nature; c) the role of the state support of agriculture in the process of implementation of the state agrarian policy and the correlation of these concepts is not defined. At the same time, the bill encountered a large number of provisions of agricultural protection nature, which did not always comply with the current legislation on state support; d) the distinction between state agricultural policy and state rural development policy [1, p. 194]. The latter, in our view, was the most significant drawback of the bill, since this approach artificially separated the whole, the object of agro-political influence. Among the positive aspects of the draft law, it should be noted, in particular, the fact of its elaboration and elaboration by the legislator of the problem of legislative support of the state agrarian policy. As you can see, the content of the analyzed bill did not fully meet the needs of the legislative support of the state agricultural policy, and its adoption in this version has led only to the multiplication of agrarian and legal problems in practice. In our opinion, the need for the drafting and adoption of the Law of the Republic of Bulgaria "On State Agrarian Policy" is quite acute now, and therefore scientific research in this area should be stepped up [4, p. 83].

Conclusions. Consequently, the scientific analysis proved the need for a clear delineation of the historical-theoretical and agrarian-legal concepts of state support for agriculture and state agrarian policy. We have come to the conclusion that state support for agriculture was a way of implementing state agrarian policy, not its separate direction, etc.

As a further direction of improving relations in the field of state support for agriculture, it would be advisable to update the legislative framework for agrarian relations, which would regulate the development of rural territories, measures of state support in the context of European integration changes.

\section{References:}

1. Башев X. Ефекти от прилагане на европейски политики вьрху земеделските стопанства в Р. България. София : ИАИ, 2018. 378 с.

2. Русчева Д. Продоволствените ресурси на България при осъществяване на Общата селскостопанска политика на ЕС. София : Унив. изд. «Св. Климент Охридски», 2010.151 с.

3. Тютюнджиев И. Стопанска история на България. София : Ровита, 2011. $204 \mathrm{c}$.

4. Натан И. Икономика на България. София: Наука и изкуство, 2013. $171 \mathrm{c}$

5. Иванов Б. Устойчивост в земеделието. София : Авангард Прима, 2009. $230 \mathrm{c}$

6. Гешов И. Думи и дела. Исторически и икономически студии. София : СУ, 2009. $290 \mathrm{c}$.
7. Rodrik, D. Economics rules: the rights and wrongs of the dismal science. New York : W. W. Norton \& Company, 2015. $192 \mathrm{c}$.

8. Страны Центральной и Восточной Европы - новые члены Европейского Союза: проблемы адаптации. / Под ред. С.П. Глинкиной, Н.В. Куликовой. Москва : Наука, 2010. С. 92.

Георгієва М. Д. Державна підтримка аграрного сектору економіки Болгарії в умовах свроінтеграції

Анотація. У статті досліджено історичні, теоретичні, правові та законодавчі проблеми співвідношення аграрно-правових категорій державної підтримки сільського господарства та державної аграрної політики. Через відсутність історичних та правових визначень аналізованих термінів пропонується їх історичне визначення. Державна аграрна політика Болгарії означає комплекс взаємопов'язаних цілеспрямованих дій уповноважених органів держави, що має на меті здійснити стратегічний вплив та сформувати певну парадигму розвитку аграрних відносин, відповідно до якої існувала гарантія продовольчої безпеки, підтримка стабільності сільськогосподарського товарного виробництва, навколишнього середовища під час сільськогосподарської діяльності, соціального розвитку болгарського села. Державна підтримка сільського господарства визначається як система заходів організаційного, фінансового та інформаційно-дорадчого характеру, що застосовуються уповноваженими державними органами та іншими суб'єктами щодо сільськогосподарських суб' єктів для виконання основних завдань аграрної політики урядом Болгарії щодо мети гарантування безпеки в законодавстві, формування стабільного середовища товаровиробників сільськогосподарської продукції, охорони навколишнього природного середовища довкілля під час здійснення сільськогосподарської діяльності, соціального розвитку болгарського села. Виявлено плюралізм наукових підходів до розуміння взаємозв'язку аналізованих категорій державної аграрної політики та державної підтримки сільського господарства. Розкрито історичне бачення співвідношення цих понять, згідно з яким державна підтримка сільського господарства розуміється як спосіб реалізації державної аграрної політики. При цьому стверджується, що слід відрізняти законодавче забезпечення правових основ державної аграрної політики та державної підтримки сільського господарства.

Протягом останніх років економіка Болгарії розвивалась порівняно високими темпами. Проте й надалі спостерігалося значне відставання в розвитку аграрного сектору економіки Болгарії від інших розвинених європейських країн. Одним 3 найдієвіших способів підвищення ефективності економіки та стимулювання іiі росту $\epsilon$ Програми розвитку сільського господарства Європейського Союзу, але в Болгарії вони, на жаль, не отримали дійсного результату. Суттєве фінансове втручання держави у становище болгарського села здійснили економічне зростання, але не призвели до стійкого та якісного розвитку. Вироблення системи державного управління та національної політики щодо аграрного сектору економіки Болгарії мало б кращий результат.

В умовах інтеграції України у світовий економічний та політичний простір важливо вивчити досвід Болгарії 3 питань державної підтримки сільського господарства. 3 тих пір Болгарія успішно просувалася до економічної стабільності в аграрному секторі, постійно розвиваючи соціальну структуру села.

Ключові слова: державна підтримка сільського господарства, аграрний протекціонізм, державна аграрна політика, аграрне право, продовольча безпека, Болгарія. 